\title{
The immune response behavior in HIV-AIDS patients treated with Ozone therapy for two years.
}

\author{
Javier Cespedes-Suarez, Yanisley Martin-Serrano, Maria Rosa Carballosa-Peña, Diana Rosa Dager- \\ Carballosa
}

Cardiozono Medical Center, Luanda, Angola

OPEN ACCESS

\section{Citation}

Cespedes-Suarez J, Martin-Serrano Y, Carballosa-Peña MR, Dager-Carballosa DR. The immune response behavior in HIV-AIDS patients treated with Ozone therapy for two years. J Ozone Ther. 2019:2(3)

doi: 10.7203/jo3t.2.3.2018.11458

Academic Editor

Jose Baeza-Noci,

School of Medicine, Valencia University, SPAIN

\section{Editor}

World Federation of Ozone Therapy, Bologna, ITALY

\section{Received}

February 1, 2018

\section{Accepted}

March 24, 2018

Published

December 15, 2018

\section{Intellectual Property}

Cespedes-Suarez J.

This is an open access article distributed under the terms of the Creative Commons Attribution License (CC BY 4.0), which permits unrestricted use, distribution, and reproduction in any medium, provided the original author and source are credited.

\section{Author Information} docj09@gmail.com

\section{ABSTRACT}

HIV continues to be one of the biggest problems for the global public health. The African region is one of the most affected, accounting for almost two thirds of the new infections. Many of them are retroviral medications and multi-therapies aiming to stop the viral replication and maintaining immunological stability, which fail to guarantee the quality of life or enhance the patient's immunity

Ozone has biological properties, among which the antimicrobial and modulatory effect on the immune response is highlighted, which makes it possible to use it in a complementary way for the treatment of these patients. We conducted the present study in which the effect of the ozone therapy administered systemically (blood route) is analyzed. We have studied 32 patients to whom we applied Major Autohemotherapy with a protocol of 15 sessions and maintenance every 15 days at $50 \mu \mathrm{g} / \mathrm{mL}$ of concentration; the initial dose was $4,000 \mu \mathrm{g} / \mathrm{mL}$ up to $12,000 \mu \mathrm{g} / \mathrm{mL}$.

We indicated viral load, CD4 and CD8 counts before and at the end of therapy. The results showed a significant decrease in viral load to undetectable values and an increase of CD4 and CD8 at the end of the 15 sessions, being maintained at 2 years of treatment, thus achieving a permanent activation of the immune system and improving the quality of life of these patients.

Keywords: Ozone therapy, HIV-AIDS, Immune Response, Major Autohemotherapy

\section{Introduction}

The Human Immunodeficiency Virus (HIV) is a retrovirus. It means that the virus genetic material consists of RNA and, once it managed to infect a cell, has the ability to convert RNA to DNA, so as to be able to incorporate their genetic material into the cells (DNA) in this case directly affecting CD4 helper T cells.

Currently, HIV continues to be one of the biggest problems for global public health, it has already taken over 35 million lives. In 2016, one million people died for causes related to this virus. At the end of that year there were approximately 36.7 million people infected with HIV worldwide, and 1.8 million new infections occurred. According to data from 2016, in the WHO African Region there were 25.6 million people infected. This Region is the 
most affected and accounts for almost two thirds of new HIV infections in the world [1].

In Angola, the adult population incidence rate was $2.7 \%$ in 2015 [2].

The HIV / AIDS treatment consists in three main parts: the disease preventive treatment, opportunistic diseases treatment and drug treatment. Of all of them the preventive treatment is the ideal right now, since there is no cure for the disease. The treatment of opportunistic diseases is based on the CD4 T cell count, is aimed at treating and preventing them, as well as prolonging the patient's life.

Drug treatment, which encompasses a large number of drugs, mainly the use of antiviral drugs such as Reverse Transcriptase (RT) inhibitors, analogues as: Zidovudine (AZT), Didanosine (Dd), Zalcitabine, Lamivudine (TC), Stavudine (DT), Combivir (Glaxo Operations UK Limited. Priory Street, Ware, Herts SG12 ODJ,United Kingdom), Abacavir and no-analogues as: Nevirapine, Efavirenz, Delavirdine.

Antiviral agents of the Protease Inhibitors (PI) type. In recent years important results have been obtained with this class of antivirals; which are characterized by high antiviral activity translating into a marked decrease in viral load and an increase in CD4 T lymphocytes. They are used in combination with analog reverse transcriptase inhibitors. In this group we found: Saquinavir, Ritonavir, Indanavir, Nelfinavir, Atazanavir, Lopinavir / ritonavir kaletra. In addition, integrase inhibitors such as Raltegravir, Stribild and Dolutegravir are also known.

Similarly, treatments based on Chemokine Coreceptor Antagonists (CCR5) have been developed which are targeted against these coreceptors by selectively inhibiting the interaction between the human CCR5 receptor and the gp120 viral glycoprotein, preventing HIV from entering the cell (Maraviroc).

Also known are fusion or entry inhibitors. These inhibit the fusion process of the glycoprotein complex gp 120 / gp 41 from the viral envelope to the cell membrane, preventing virus penetration (Enfuvirtide). In the case of treatments based on fixed combinations (combination of several active ingredients in a single tablet or capsule), several drugs have been developed as Combivir, Trizivir and Kivexa (Glaxo Operations UK Limited. Priory Street, Ware, Herts SG12 0DJ,United Kingdom), Kaletra (AbbVie Inc., 1 North Waukegan Rd, North Chicago, IL 60064, USA), Truvada, Atripla, Complera, Eviplera and Stribild (Gilead Sciences Inc., 333 Lakeside Drive, Foster City, CA 94404,).

The conditions for treatment initiation are:

Evaluation of the CD4 count for initiation of antiretroviral therapy (ARVT):

- Less than 200 cells / $\mathrm{mm}^{3}$ : treat regardless of clinical stage.

- From 200-350 cells / $\mathrm{mm}^{3}$ : is recommended, because it is considered that at this level there is a functional immune deficiency.

- >350-500 cells / $\mathrm{mm}^{3}$ : no treatment is recommended; except for some special conditions [3].

Despite these advances, there are still factors that limit the achievement of good long-term results. In a research protocol (termed ACTG 320 clinical trial) the combination of Zidovudine, Lamivudine and Indinavir did not suppress plasma detectable viral load in $60 \%$ of patients with advanced 
disease. The same occurred in $50 \%$ of patients treated with a regimen based on Indinavir or Ritonavir. Because the cross-resistance frequency to all three types of antiretroviral drugs (nucleoside and non-nucleoside reverse transcriptase inhibitors and protease inhibitors), failure with one regimen limits future treatment options. This implies the need to develop new drugs, a slowly progressing process $[4,5]$.

Faithful adherence to HIV treatment is not always easy and, in some cases, impossible. Side effects and interaction with other medications are common. These effects call into question the innocuousness of the newest treatments when used for prolonged periods [6].

On the other hand, there are also other natural treatments that perfectly complement the pharmacological ones. Multiple references point to ozone therapy as an encouraging alternative for HIV-infected patients. Recent studies show that, in addition to potentiating the effect of antiretrovirals, it is useful in the prevention and treatment of many complications of this disease $[7,8]$.

Ozone therapy alone has very significant effects as a modulator of the immune system, and oxidative stress. When oxidative stress is small, transient and controlled, it restores the antioxidant defense systems needed in these seropositive patients who are in chronic oxidative stress $[9,10,11]$.

Ozone increases the production of interferon's that have the ability to interfere in the replication of viruses in host cells. Gamma interferon levels can be raised from $400 \%$ to $900 \%$ with their antiviral activity. They prevent viral replication and activate CD4 + T lymphocytes (helper), immunomodulatory functions and natural killer cells (cytotoxic). Also induce the cytotoxicity of CD8 + T lymphocytes, promotes the proliferation and B lymphocytes activation, which is why these cells are considered a fundamental pillar in the mediated-cell immune response. The CD4 + T lymphocytes activation trigger an immune reactions cascade [12,13]. CD8 + T lymphocytes, macrophages, neutrophils, eosinophils, NK cells and the activation of antibody-dependent cellular cytotoxicity (ADCC) constitute immune effectors mechanisms to destroy virus-infected cells [14]. Previous studies have shown different types of ozone treatments against HIV infection [15]. Considering this background, the aim of this study is to demonstrate the immunological response in HIV-AIDS patients treated with ozone by major autohemotherapy during 2 years.

\section{Materials and methods}

A retrospective longitudinal study was performed at the Cardiozono Medical Center located in Luanda, Angola. Thirty-two patients with no gender distinction were included. They began treatment at the Medical Center in August 2015 until August 2017, submitted to our Clinic from an Infectology Consultation and other Hospitals, with 1-3 years of seropositive diagnosis.

9 patients were male $(28.1 \%)$ and $23(71.9 \%)$ were female. The age ranged from 32 up to 48 years old. The groups with the highest incidence of disease were the ranges $36-45$ and $46-55$ years.

Inclusion criteria: HIV positive patients with high viral load and low CD4 and CD8 counts, under retroviral treatment (Lamivudine $150 \mathrm{mg}$ and Zidovudine $300 \mathrm{mg}$ one tablet daily) suffering the adverse effects of retroviral. 
Exclusion criteria: HIV positive patients who did not comply with the treatment time and serological results expressed in the inclusion criteria. Pregnant women and patients under 18 years of age.

Treatment Protocol: The patients received 15 sessions of major autohemotherapy (one daily session). In each session we used a Germanmade Promedic Humazon equipment (Humares $\mathrm{GmbH}$, Bruchsal, Germany), 3-way stopcock, epicranial needle 19 G, Sangiset (Humares $\mathrm{GmbH}$, Bruchsal, Germany) with capacity of $350 \mathrm{~mL}$ where we put $10 \mathrm{~mL}$ of $3.13 \%$ sodium citrate to avoid blood clot during the procedure and other disposable material.

The major autohemotherapy (Table 1) was performed at a concentration of $50 \mu \mathrm{g} / \mathrm{mL}$ in $100 \mathrm{~mL}$ of blood; the initial dose of the therapy was $2000 \mu \mathrm{g}$ (40 mL of ozone gas at $50 \mu \mathrm{g} / \mathrm{mL}$ concentration); we increased the dose by $2000 \mu \mathrm{g}$ every 2 days until reaching a dose of $12000 \mu \mathrm{g}(240 \mathrm{~mL}$ of ozone gas at $50 \mu \mathrm{g} / \mathrm{mL}$ concentration), keeping this dose as a maintenance dose every 15 days throughout the year.

Table 1: Treatment protocol.

Days of treatment

Ozone dose in $\mu \mathrm{g}$ in $100 \mathrm{ml}$ blood (concentration and volumen of ozone)

\begin{tabular}{cc}
\hline Days 1-2 & $2000(50 \mu \mathrm{g} / \mathrm{mL}$ and $40 \mathrm{ml})$ \\
Days 3-4 & $4000(50 \mu \mathrm{g} / \mathrm{mL}$ and $80 \mathrm{ml})$ \\
Days 5-6 & $6000(50 \mu \mathrm{g} / \mathrm{mL}$ and $120 \mathrm{ml})$ \\
Days 7-8 & $8000(50 \mu \mathrm{g} / \mathrm{mL}$ and $160 \mathrm{ml})$ \\
Days 9-10 & $10000(50 \mu \mathrm{g} / \mathrm{mL}$ and $200 \mathrm{ml})$ \\
Days 11-15 & $12000(50 \mu \mathrm{g} / \mathrm{mL}$ and $240 \mathrm{ml})$ \\
Maintenance every 15 days & $12000(50 \mu \mathrm{g} / \mathrm{mL}$ and $240 \mathrm{ml})$ \\
\hline
\end{tabular}

Evaluation criteria (before and after treatment): Results of the viral load, CD4 and CD8 counts per month and every 6 months, until 2 years of therapy.

The real-time PCR reference values were taken into account as a standardized method to determine Viral Load with an analytical range of 50-300,000 copies/mL. This technique was developed in a clinic authorized for the diagnosis of this virus

CD4 values with a range of $500-1600$ cells $/ \mathrm{mm}^{3}$ and CD8 of $375-1100$ cells $/ \mathrm{mm}^{3}$ were taken into account according to the reference of the clinical laboratory in which these tests were performed.

Statistical analysis: We used SPSS 19.0 statistic software and we categorized the values using contingency tables utility and chi-square analysis for the significance on the changes before and after the treatment. Values of chi-square under 0,05 were considered significant.

Side effects evaluation: As a marginal target, the increase in the quality of life referred by most of the patients and the decrease in the rate of side effects made us compile them in an open list way and calculate incidence rate before and after the treatment. 


\section{Results}

Before starting treatment, most patients had a viral load between $15,000-20,000 \mathrm{IU} / \mathrm{ml}$ for $46.9 \%$, and after one month the viral load was undetectable in $100 \%$ of the sample during the 2 years under treatment (Table 2).

Table 2: Viral load behavior in 32 patients treated with ozone therapy at the beginning and after 1, 6, 12, 18 and 24 months ( 2 years) of treatment.

\begin{tabular}{ccccccc}
$\begin{array}{c}\text { Viral load } \\
\text { (RNA copies/mL) }\end{array}$ & $\begin{array}{c}\text { Before } \\
\text { treatment }\end{array}$ & $\begin{array}{c}\mathbf{1} \\
\text { month }\end{array}$ & $\begin{array}{c}\mathbf{6} \\
\text { months }\end{array}$ & $\begin{array}{c}\mathbf{1 2} \\
\text { months }\end{array}$ & $\begin{array}{c}\mathbf{1 8} \\
\text { months }\end{array}$ & $\begin{array}{c}24 \\
\text { months }\end{array}$ \\
\hline No detectable & 0 & $\begin{array}{c}32 \\
(100 \%)^{*}\end{array}$ & $\begin{array}{c}32 \\
(100 \%)^{*}\end{array}$ & $\begin{array}{c}32 \\
(100 \%)^{*}\end{array}$ & $\begin{array}{c}32 \\
(100 \%)^{*}\end{array}$ & $\begin{array}{c}32 \\
(100 \%)^{*}\end{array}$ \\
$\begin{array}{c}10000-15000 \\
\mathrm{Ul} / \mathrm{mL}\end{array}$ & $\begin{array}{c}8 \\
(25 \%)\end{array}$ & 0 & 0 & 0 & 0 & 0 \\
$\begin{array}{c}15000-20000 \\
\mathrm{Ul} / \mathrm{mL}\end{array}$ & $\begin{array}{c}15 \\
(46.9 \%)\end{array}$ & 0 & 0 & 0 & 0 & 0 \\
$20000-25000$ & 9 & 0 & 0 & 0 & 0 & 0 \\
$\mathrm{U} / \mathrm{mL}$ & $(28.2 \%)$ & 0 & & & & \\
\hline
\end{tabular}

${ }^{*}$ chi-square significant value

The results on the kinetics cell populations of TCD4 and TCD8 are shown in Tables 3 and 4. Before starting the treatment, the highest number of patients had a CD4 count between $250-300$ cells / mm3 for $71.9 \%$. At one month, $53.1 \%$ presented values between $550-600$ cells $/ \mathrm{mm} 3$, reaching the ranges between $600-700$ and $700-800$ cells / mm3 at 6 months, being maintained at one and at two years in $100 \%$ of patients (Table 3 ).

In the case of CD8 cells, the highest number of patients had a CD8 count between $240-300$ cells / mm3 for $81.3 \%$, before starting treatment. At one month, $59.4 \%$ presented values ranging from $400-450$ cells / mm3, to $500-1000$ cells / $\mathrm{mm} 3$ at 6 months, and remained within 2 years of treatment in $100 \%$ of patients (Table 4 ).

The patients presented with side effects of antiretroviral therapy are as following:

- Decay

- Lack of appetite,

- Insomnia,

- Nausea, Headache,

- Gastric discomfort.

We can see in Table 5 the evaluation after the treatment. In 7 patients, all side effects disappeared. 
Table 3: CD4 behavior in 32 patients treated with ozone therapy at the beginning and after 1, 6, 12, 18 and 24 months (2 years) of treatment.

\begin{tabular}{|c|c|c|c|c|c|c|}
\hline $\begin{array}{c}\text { CD4 } \\
\text { cells/mm } 3\end{array}$ & $\begin{array}{l}\text { Before } \\
\text { treatment }\end{array}$ & $\begin{array}{c}1 \\
\text { month }\end{array}$ & $\begin{array}{c}6 \\
\text { months }\end{array}$ & $\begin{array}{c}12 \\
\text { months }\end{array}$ & $\begin{array}{c}18 \\
\text { months }\end{array}$ & $\begin{array}{c}24 \\
\text { months }\end{array}$ \\
\hline $250-300$ & $\begin{array}{c}23 \\
(71.9 \%)\end{array}$ & & & & & \\
\hline $300-350$ & $\begin{array}{c}9 \\
(28.1 \%)\end{array}$ & & & & & \\
\hline $450-500$ & & $\begin{array}{c}15 \\
(46.9 \%)^{*}\end{array}$ & & & & \\
\hline $550-600$ & & $\begin{array}{c}17 \\
(53.1 \%)^{*}\end{array}$ & & & & \\
\hline $600-700$ & & & $\begin{array}{c}11 \\
(34.4 \%)^{*}\end{array}$ & $\begin{array}{c}8 \\
(25 \%)^{*}\end{array}$ & $\begin{array}{c}7 \\
(21.9 \%)^{*}\end{array}$ & $\begin{array}{c}5 \\
(15.6 \%)^{*}\end{array}$ \\
\hline $700-800$ & & & $\begin{array}{c}21 \\
(65.6 \%)^{*}\end{array}$ & $\begin{array}{c}24 \\
(75 \%)^{*}\end{array}$ & $\begin{array}{c}25 \\
(78.1 \%)^{*}\end{array}$ & $\begin{array}{c}27 \\
(84.4 \%)^{*}\end{array}$ \\
\hline
\end{tabular}

${ }^{*}$ chi-square significant value

Table 4: Behavior of CD8 in 32 patients treated with ozone therapy at the beginning and after 1, 6, 12, 18 and 24 months (2 years) of treatment

\begin{tabular}{|c|c|c|c|c|c|c|}
\hline $\begin{array}{c}\text { CD8 } \\
\text { cells } / \mathrm{mm}^{3}\end{array}$ & $\begin{array}{l}\text { Before } \\
\text { treatment }\end{array}$ & $\begin{array}{c}1 \\
\text { month }\end{array}$ & $\begin{array}{c}6 \\
\text { months }\end{array}$ & $\begin{array}{c}12 \\
\text { months }\end{array}$ & $\begin{array}{c}18 \\
\text { months }\end{array}$ & $\begin{array}{c}24 \\
\text { months }\end{array}$ \\
\hline $240-300$ & $\begin{array}{c}26 \\
(81.3 \%)\end{array}$ & & & & & \\
\hline $300-330$ & $\begin{array}{c}6 \\
(18.7 \%)\end{array}$ & & & & & \\
\hline $400-450$ & & $\begin{array}{c}19 \\
(59.4 \%)^{*}\end{array}$ & & & & \\
\hline $450-500$ & & $\begin{array}{c}13 \\
(40.6 \%)^{*}\end{array}$ & & & & \\
\hline $500-700$ & & & $\begin{array}{c}11 \\
(34.4 \%)^{*}\end{array}$ & $\begin{array}{c}9 \\
(28.1 \%)^{*}\end{array}$ & $\begin{array}{c}8 \\
(25 \%)^{*}\end{array}$ & $\begin{array}{c}7 \\
(21.9 \%)^{*}\end{array}$ \\
\hline $700-1000$ & & & $\begin{array}{c}21 \\
(65.6 \%)^{*}\end{array}$ & $\begin{array}{c}23 \\
(71.9 \%)^{*}\end{array}$ & $\begin{array}{c}24 \\
(75 \%)^{*}\end{array}$ & $\begin{array}{c}25 \\
(78.1 \%)^{*}\end{array}$ \\
\hline
\end{tabular}

${ }^{*}$ chi-square significant value 
Table 5: Antiretroviral side effects incidence before and after the treatment.

\begin{tabular}{lccc}
$\begin{array}{l}\text { Side } \\
\text { effect }\end{array}$ & $\begin{array}{c}\text { Before } \\
\text { treatment }\end{array}$ & Improvement & Aisappearance \\
\hline decay & $32(100 \%)$ & & $32(100 \%)^{*}$ \\
lack of appetite & $32(100 \%)$ & & $32(100 \%)^{*}$ \\
insomnia & $32(100 \%)$ & & $32(100 \%)^{*}$ \\
gastric discomfort & $30(93,75 \%)$ & $7(21,88 \%)^{*}$ & $23(71,87 \%)^{*}$ \\
nausea & $28(87,5 \%)$ & $4(12,5 \%)^{*}$ & $24(75 \%)^{*}$ \\
headache & $20(62,5 \%)$ & $6(18,75 \%)^{*}$ & $14(43,75 \%)^{*}$ \\
\hline
\end{tabular}

${ }^{*}$ chi-square significant value

\section{Discussion}

The HIV infection evolution is closely related to the immune response, that the patient can achieve the effectiveness and control of viral replication. There have been different studies that suggest that a cell response mediated by helper T cells (CD4), cytotoxic T lymphocytes (CD8) together with NK cells predict a favorable prognosis in the control of HIV infection, where there is a gradual loss of CD4 lymphocytes because these are the target cells of this retrovirus. Likewise, in the immune response to HIV, NK cells play an important defensive role due to the CD4 rapid decrease, these NK cells are of vital importance because they do not have CD4 receptors and some of them are resistant receptors to HIV infection virus. Considering the implication of the immune system in the pathogenesis of HIV infection, as well as the immunomodulatory effect of ozone therapy on TCD4, TCD8 and NK cells, we have evaluated the efficacy of a treatment based on increased autohemotherapy against HIV in infected patients [16,17].

Taking into account the values obtained after counting CD4 and CD8 T cell populations at 6 months of treatment, as well as the impossibility of detecting viral RNA during the first month of treatment and during the two years of this study, our results show that the treatment with major autohemotherapy acted as a modulator of the immune system and as an enhancer of current antiretroviral therapy. It is important to note that the treatment employed was able to maintain undetectable viral load during the two years of treatment, resulting in a potentiating effect on the number of T cells (CD4 and CD8) during this time. Our results are similar to those previously obtained by Gonzalez et al., 2003 [18], and Méndez et al., 2005 [15], although in Mendez study, ozone treatment was administered rectally. This can be an option when major autohemotherapy can't be performed and the results are the same $^{20}$ adjusting the dosification. Due to cultural reasons in Angola, rectal insufflation is usually refused.

We must also point out an important aspect, HIV infection causes oxidative stress in these patients, this is because in their pathogenesis and evolution, reactive oxygen species (ROS) may be involved. The oxidative stress acts on the immune system, producing a decrease in the intracellular antioxidant systems and therefore an increase in the apoptosis of the cells of the 
immune system (for example TCD4 cells) ${ }^{21}$. The induction of an oxidative stress with medical ozone, through controlled treatments (for example, main autohemotherapy) stimulates the endogenous antioxidant systems that control the excessive production of ROS, by Diaz L. et al., 2018 [22], thus supporting the activation of the system through the decrease as a consequence of the apoptosis of the TCD4 cells, which in turn are attacked by the virus.

\section{Conclusions}

Our results support previous studies that demonstrate the immunomodulatory potential of ozone, as well as the beneficial effect of ozone therapy at the level of the immune system, in the control of oxidative stress and its relationship with the immune response that improves HIV infection. Considering that there is not much information in the scientific literature on this type of strategies, this work provides information on the immunomodulatory capacity of ozone against one of the most relevant infections in human health that does not yet have an effective treatment.

No side effects were presented because of the ozone treatment. The quality of life improved not only because the improvement of the immunological status but also thanks to the decrease of antiretroviral therapy side effects.

We recommend carrying out studies with a greater number of patients, including other parameters to be studied, so that the introduction of ozone therapy in HIV-AIDS treatment protocols could be considered in the future.

\section{References}

1. WHO. HIV/AIDS [internet]. Geneve: WHO; 2018 [cited 2017 Jul 20]. Available from: https://www.who.int/es/news-room/fact-sheets/detail/hivaids

2. Index Mundi. Angola HIV/AIDS adult prevalence rate [internet]. Charlotte (NC): Index Mundi; 2016 [cited 2017 Feb 02]. Available from: https:// www.indexmundi.com/angola/hiv_aids_adult_prevalence_rate.html

3. Vicente-Peña E. Medicina Interna. Diagnóstico y Tratamiento [Internal Medicine. Diagnosis and Treatment]. 2nd ed. La Havana: Editorial Ciencias Médicas; 2016.

4. Hammer SM, Squires KE, Hughes MD, Grimes JM, Demeter LM, Currier JS, et al. A controlled trial of two nucleoside analogues plus indinavir in persons with human immunodeficiency virus infection and CD4 cell counts of 200 per cubic millimeter or less. AIDS Clinical Trials Group 320 Study Team. N Engl J Med. 1997 Sep;337(11):725-733. doi: 10.1056/ NEJM199709113371101.

5. Demeter LM, Hughes MD, Coombs RW, Jackson JB, Grimes JM, Bosch $\mathrm{RJ}$, et al. Predictors of virologic and clinical outcomes in HIV-1-infected patients receiving concurrent treatment with indinavir, zidovudine, and lamivudine. AIDS Clinical Trials Group Protocol 320. Ann Intern Med. 2001 Dec;135(11):954-964.

6. Volberding PA, Deeks SG. Antiretroviral therapy for HIV infection: promises and problems. JAMA. 1998;279(17):1343-1344.

7. Bocci V. Oxygen-Ozone Therapy. A Critical Evaluation. Dordrecht (NL): Kluwer Academic Publishers; 2002. 440 p. ISBN: 9789401599528. 
8. Bocci V. Ozone. A new medical drug. Dordrecht (NL): Springer; 2005. 324 p. ISBN: 9789048192342.

9. Travagli V, Zanardi I, Silvietti A, Bocci V. A physicochemical investigation on the effects of ozone on blood. Int J Biol Macro Mol. 2007;41(5): 504-511. doi: 10.1016/j.ijbiomac.2007.06.010.

10. Larini A, Bocci V. Effects of ozone on isolated peripheral blood mononuclear cells. Toxicol in Vitro. 2005 Feb;19(1):55-61. doi: 10.1016/ j.tiv.2004.06.007.

11. Abbas AK. Activation of lymphocytes. In: Abba AK, Lichtman A. Cellular and Molecular Immunology. 7th ed. New York (NY): WB Saunders Co. 2011. p. 203-224. ISBN: 9780323278423.

12. Hooker MH, Gazzard BG. Ozone-treated blood in the treatment of HIV infection. AIDS. 1992 Jan;6(1):131.

13. Huanqui P, Cruz M, Miranda A, Patrica P, Mamani R. Eficacia y seguridad del ozono intraarticular en ambas rodillas refractaria al tratamiento [Efficacy and safety of intraarticular ozone in both knees refractory to treatment.]. Rev Peru Reum. 2006;12(1):21-26. Available from: http:// www.sld.cu/galerias/pdf/sitios/rehabilitacion-doc/gonartrosis_ozono.pdf

14. Rhee SG, Bae YS, Lee SR, Kwon J. Hydrogen peroxide: a key messengers that module protein phosphorylation through cysteine oxidation. Sci STKE. 2000;2000(53):1. doi: 10.1126/stke.2000.53.pe1.

15. Mendez I, Menendez S, Rivero J. Ozonoterapia en SIDA. Reporte de un caso [Ozone therapy in AIDS. A case report]. Rev Cubana Invest. Biomed. 2005;24(1):69-71. Availble from: http://scielo.sld.cu/pdf/ibi/ v24n1/ibi09105.pdf

16. Li Q, Verma IM. Nf-kB regulation in the immune system. Nat Rev Immunol. 2002 Oct; 2(10):725-734. doi: 10.1038/nri910.

17. Reth M. Hydrogen peroxide as second messenger in lymphocyte activation. Nat. Immunol. 2002;3(12):1129-1134. doi: 10.1038/ ni1202-1129.

18. Gonzalez-Ramirez J. Caso clínico Paciente pediátrico con VIH [Case report. A HIV pediatric patient]. Ciudad de Mexico: Asociacion Mexicana para el diagnostico y tratamiento de enfermedades autoinmunes, AC; 2016 [cited 2017 Jul 20]. Available from: http:// www.autohemoterapia.org.mx/casos-clinicos/pac-pediatrico-con-vih.pdf

19. Abbas AK. Cytokines- appendix II. In: Abba AK, Lichtman A. Cellular and Molecular Immunology. 7th ed. New York (NY): WB Saunders Co; 2011. p. 501-504. ISBN: 9780323278423.

20. Bocci V, Luzzi E, Corradeshi F, Paulesu L, Di-Stefano A. Studies on the biological effects of ozone: 3 . An attempt to define conditions for optimal induction of cytokines. Lymphokine Cytokine Res. 1993 Apr;12(2): 121-126.

21. Garber GE, Cameron DW. The use of ozone-treated blood in the therapy of HIV-infection and immune disease: a pilot-study of safety and efficacy. AIDS. 1991;5(8):981-984.

22. Díaz-Luis J, Menéndez-Cepero S, Macías-Abraham C, Fariñas-Rodríguez L. Systemic ozone therapy by rectal insufflation for Immunoglobulin A deficiency. MEDICC Review. 2018 Jan;20(1):29-35. Available from: http:// mediccreview.org/wp-content/uploads/2018/04/mr_616.pdf 